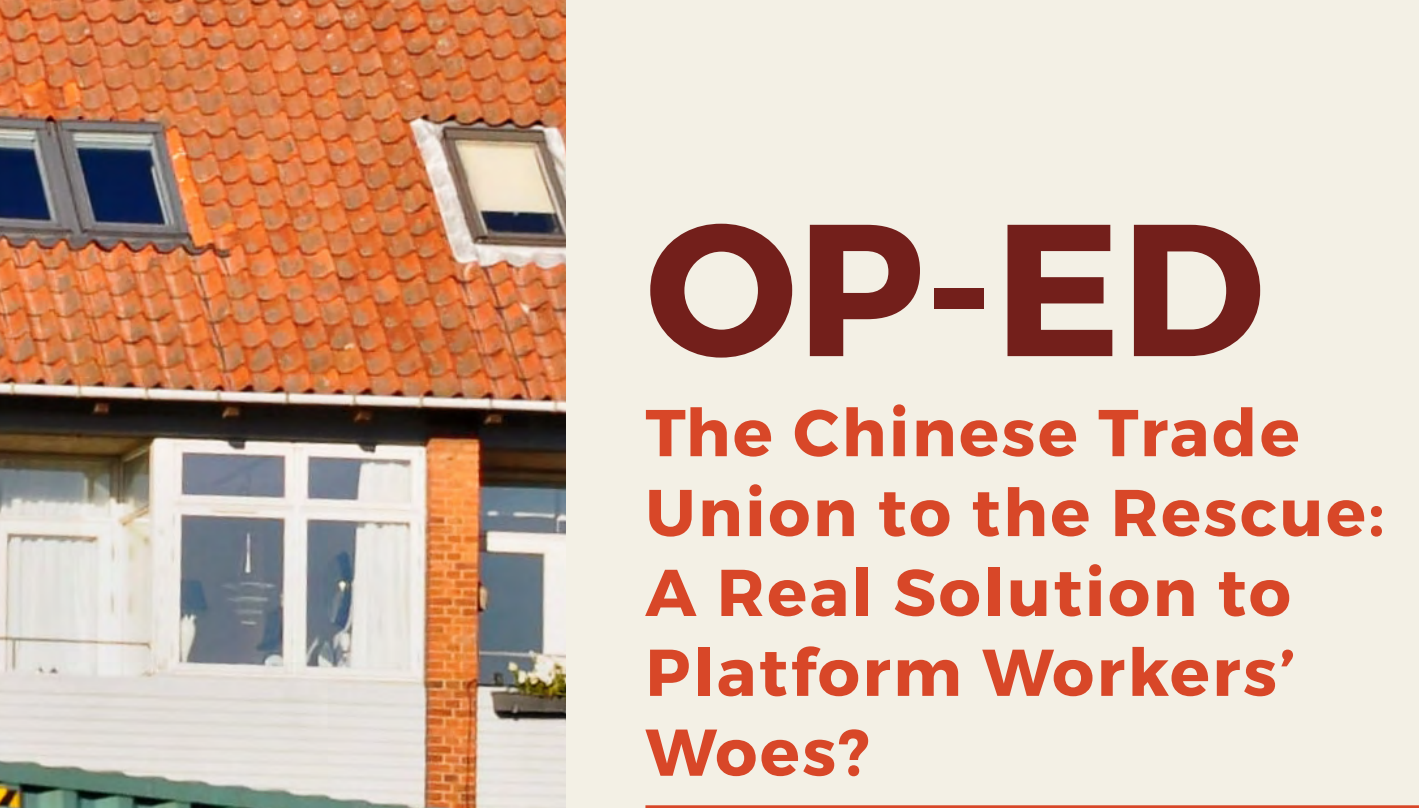

\section{Kevin LIN}

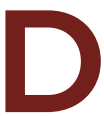

uring a conversation we had a few years ago, an international trade unionist shared with me an anecdote from a recent encounter with a Chinese trade union. A delegation of the All-China Federation of Trade Unions (ACFTU) had travelled overseas and met with his organisation as part of semi-regular exchanges. This was at a time when such international meetings between trade unionists in China and elsewhere were frequent, and when there was much mutual interest in learning about each other's labour development and trade union activities (Quan 2017). In their meeting, among other topics, the ACFTU delegation inquired about organising truck drivers, which the said trade union was known for. Why would the ACFTU delegation be interested in this? The encounter took place not long after a truck drivers' strike across multiple cities in China, in June 2018. During the period of militant strikes by factory workers in the early 2010s, strikes by truck drivers were rare, and even rarer were strikes coordinated across the country. This must have concerned the ACFTU, especially considering its inability to grasp how to address the grievances of truck drivers.

The ACFTU did not have much experience with truck drivers, and not just because they did not protest as much as their counterparts in factories. As often happens, such a shortcoming was also shaped by the institutional structure of the ACFTU, which, from the national headquarters all the way down to its provincial, municipal, and district levels, mirrors that of the government-that is, primarily based on administrative regions. Even though it does have some affiliates organised along sectoral lines, the ACFTU is for the most part not structured according to industries and sectors like most traditional trade unions around the world. Typically, trade unions emerge from organising at the workplace level and then federate along industrial lines; in addition, you might see city and

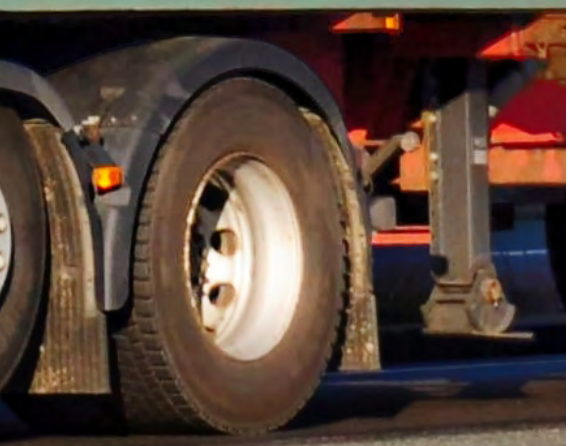


Previous calls by the

ACFTU to unionise

delivery and other

platform workers,

in 2015 and 2018,

reportedly increased

union membership by

more than 6 million,

but it is unclear to what

extent these unions

protected workers'

rights regional-level trade union councils and federations that coordinate industrial unions within their region. This is not the case with the ACFTU, which is organised on the Leninist principle of democratic centralism, in a vertical structure mirroring the layers of the PartyState. So, when workers in the same industry but in different workplaces across multiple cities have a common grievance, the ACFTU finds itself ill-equipped to deal with the situation.

It turns out that the striking Chinese truck drivers were protesting high petrol prices and arbitrary traffic fines, as well as the unfair practices of the platform companies that hired them as independent contractors. Just as the platform economy has now subsumed ridehailing and delivery in China, it has also penetrated the long-haul transportation industry that supports China's e-commerce logistics infrastructure (Lin and Pun 2021). The platform in question was operated by Manbang, a conglomerate that operates in much the same way as Didi or Uber, by sending out orders and getting truck drivers to compete for them. Following a pattern common to platform capital elsewhere, before the strikes, Manbang had executed a merger of two transportation platforms to secure a near monopolistic position in the industry. Its monopolistic practices put downward pressure on the truck drivers' incomes by compelling them to lower their rates. This situation thus presented a new set of challenges from the more traditional employment relations most familiar to the ACFTU.

\section{Deja Vu}

Recent official announcements by Chinese ministries such as the Ministry of Human Resources and Social Security and the Supreme People's Court regarding the illegality of the tech companies' working-hour practices-the so-called 996 culture of working from 9 am to $9 \mathrm{pm}$, six days a week-and orders for tech companies to establish trade unions represent the latest attempts by the Chinese authorities to address labour rights violations in the platform economy (Supreme People's Court 2021). Previous calls by the ACFTU to unionise delivery and other platform workers, in 2015 and 2018, reportedly increased union membership by more than 6 million, but it is unclear to what extent these unions protected workers' rights (China National Radio 2020). In response to these latest developments, in early September, big names in the platform economy such as Didi and JD announced that they had established unions (Toh 2021). However, the very fact they made such an announcement should be reason for caution and even scepticism. To observers of Chinese labour relations over the past few decades, a lot of this feels like deja vu. Only a decade ago, in the wake of the dislocation caused by the 2008 Global Financial Crisis and a historic strike by workers at a Honda plant in Guangdong in 2010, we heard similar calls by the authorities for companies to rectify labour rights violations and 
establish unions (Worker Daily 2010). Then, as now, labour unrest concerned the authorities, and the ACFTU was called in to undertake the unionising of workers in previously non-unionised sectors.

Even before that, highly publicised unionisation campaigns had focused on transnational companies such as Walmart and Foxconn. In the mid to late $2000 \mathrm{~s}$, one of the most notorious anti-union companies in the world, Walmart, became a target of the ACFTU as it sought to establish a degree of control in foreign-owned businesses. Workplace unions were established with considerable and sometimes direct ACFTU support at Walmart stores in China (Chan 2007), even though management would later thwart these unions through targeted firings and by getting their own people to compete for election (Unger et al. 2011). And, in the early 2010s, trade unions were similarly established in Foxconn after public pressure to improve workers' conditions following a string of employee suicides in 2010. The union at Foxconn went as far as to hold a supposedly democratic election for union leadership, even though the records of these trade unions were less than impressive, with the company seeming to have shunned the development of the trade union in its mega-facilities from the very beginning, as evidenced by the fact that many workers were not aware of and did not participate in the union election (Chan 2017).

\section{Restarting from Scratch}

It seems that Chinese workers are now having to start from scratch again. It is by design that workers in the platform economy are being recommodified in the sense of being denied legal protections associated with employment relations. As most platform workers are classified as independent contractors, the gains in legal protection and a more balanced labour-management relationship brought by factory workers and labour activists over the past three decades do not much apply to them and they have once again had to rediscover how to protect themselves from blatant rights violations and managerial abuses. However, they seem to be learning fast, if recent waves of protest are any indication (Liu and Friedman 2021).

The situation looked rather different a decade ago, towards the end of the Hu Jintao and Wen Jiabao era. Fundamental labour and trade union reforms were in the air, and discussions of worker representation and collective bargaining were all the rage at academic conferences and labour NGO gatherings (Franceschini and Lin 2019). Policymakers openly recognised the need for such reforms. In retrospect, the foundation of worker representation and collective bargaining in the experiments that took place at the time was still weak and limited to certain regions and workplaces, and the reforms had powerful opponents within the ACFTU. However, it is undeniable that there was a real yearning for and momentum towards the formalisation of union representation that accepted a growing 
degree of worker participation through the democratic election of trade union representatives. This was to incorporate workers into the emerging industrial relations system and counter growing workers' strength through institutionalisation. Even with this rather moderate goal, it was widely pointed out by scholars and activists that any trade union imposed from above by either the ACFTU or employers would be unlikely to represent and involve workers.

At that time, the broader circumstances were much more favourable for the trade unions to play a meaningful, if still constrained, role. While most factory workers were primarily concerned with wage issues and uninterested in unions, there were many workers who were genuinely looking to create membership-run unions because they realised that, without worker representation, the problems they had to deal with would recur. Moreover, momentum for better labour protection at the national level under the 'Harmonious Society' agenda created space at the local level to experiment with trade union reforms that allowed limited worker participation (Pringle 2011). In that context, all kinds of local trade union experiments took place, however uneven in their degree of worker participation and success.

These factors are largely missing today. The recent protests by delivery workers in China have not generated any strong demands for trade union representation despite the emergence of informal networks among platform workers across the country that served as mutual aid and organising tools. Chen Guojiang, commonly known as Mengzhu, led the most noticeable effort to create a semi-formal structure for workers to make their demands explicit (Mengzhu 2020). For this, he was detained, along with several other delivery workers, in February 2021. In this sense, these mobilisations are part of a global pattern that sees platform workers in some countries seeking better pay directly, while in others, focusing more of their organising on legal recognition of their employee status and union representation (Joyce et al. 2020). The pattern is, of course, not absolute, may vary over time, and is contingent on the local industrial relations system and trade union movement. However, without grassroots demands for trade union representation, there is a near certainty that any union established by companies will end up being controlled and manipulated by employers. In addition, the ACFTU's internal momentum for reforms has retreated significantly since the 2000s. While it may still talk about unionising workers, the momentum and space for reforms to increase worker representation are simply not there anymore.

\section{Common Prosperity?}

While genuine worker representation remains elusive, many still have some hope that the broader regulatory crackdown will put enough pressure on companies to make much needed changes as 
part of the 'Common Prosperity' (共同富裕) agenda. There are signs that companies have been complying better with the law. For instance, the reduction of working hours is already happening in some tech companies under regulatory pressure, but the government is performing a delicate balancing act, too. At the same time as it tightened regulation over tech companies, a People's Daily (2021) front-page article sought to reassure the commercial sector that private business interests were still respected. It emphasised that

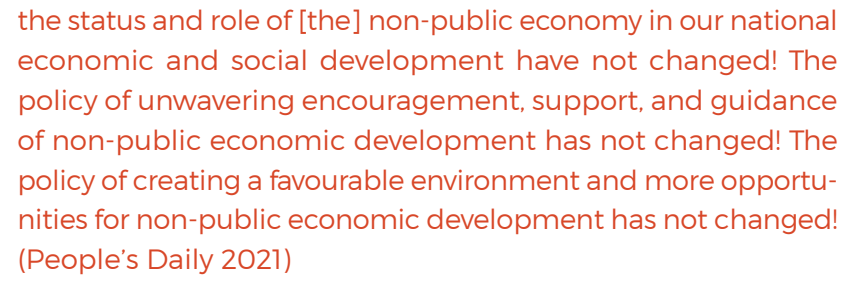

This rather pessimistic assessment can perhaps be balanced by the fact that the issues of working hours and overwork are a much more mainstream concern than a decade ago. This is largely because these issues have been afflicting white and blue-collar workers alike-that is, a large percentage of the working population. This means the problem can no longer be relegated to the side, out of public view, seen as relevant only to migrant factory workers. It also cannot be dismissed as the unreasonable demands of a few individual labour activists, labour lawyers, or academics. As a society-wide conversation about work has already taken off, even setting up unions in a couple of big companies or holding them legally accountable may be too little, too late in addressing concerns that are deeply rooted in the labour recommodification brought about by the platforming of work.

If the global pattern of platform workers organising across all sorts of political and economic systems is any guide, when workers cannot depend on established trade unions to channel their grievances, they may opt to start their own informal networks and organise grassroots unions of their own, as we have witnessed in China and elsewhere. This is despite all the (mis)conceptions about platform workers lacking the power of factory workers. Such global momentum towards labour organising in the platform economy is unmistakable and shows no sign of slowing, even recognising that Chinese workers face considerable constraints on their ability to mobilise. There is no shortcut. We are and should be moving back to the basics of labour interest representation. Only authentic worker participation and representation will ensure that workers' rights are properly protected. 
This text is taken from Made in China Journal: Volume 6, Issue 2, 2021, edited by Ivan Franceschini and Nicholas Loubere, published 2021 by ANU Press, The Australian National University, Canberra, Australia.

$$
\text { doi.org/10.22459/MIC.06.02.2021.01 }
$$

